\title{
Financial Literacy and Retirement Preparedness among University of Bohol Employees
}

\author{
MA. LIEZL CONCEPCION-GALLARDO \\ ORCID No.: 0000-0003-3566-3069 \\ mlcgallardo@universityofbohol.edu.ph \\ BUENAVENTURADA O. LIBOT \\ ORCID No.: 0000-0002-9863-2182 \\ bdlibot@universityofbohol.edu.ph
}

\begin{abstract}
Financial literacy refers to the awareness and knowledge of business and finance, financial capability, money management and financial planning, which is a vital tool for retirement preparedness. This paper has investigated the level of retirement preparedness of the UB Employees vis-à-vis its level of financial literacy. The study applied a quantitative approach, utilizing the descriptive-normative survey method with a modified survey questionnaire. The quantitative data collected were coded to ensure the confidentiality of the data. The analysis, comparison and checking for similarities or differences on financial literacy in correlation with retirement preparedness were statistically treated using the Pearson Product Moment Correlation, Chi-Square, and t-test. Based on the results, it showed that there is a negative correlation between financial literacy and the level of retirement preparedness. In conclusion, a high level of financial literacy does not translate preparation for life after employment. Young professionals are slightly financially literate than their older counterparts. However, most of them do not have any investments allotted for retirement. Implications of this study would serve as the basis in attaining the employees' goal for their retirement preparation and will form part of their corporate social responsibility (CSR) project for the employees.
\end{abstract}




\section{KEYWORDS}

Financial literacy, retirement preparedness, quantitative approach, descriptive-normative, Pearson Product Moment Correlation, Chi-Square, t-test, Philippines, Asia

\section{INTRODUCTION}

"We are trained to be great employees, but no one ever prepared us for life after employment."

Laraya, (2014)

Retirement is inevitable but how many people had prepared for this eventuality? How many have savings or even toying with the idea of saving for the future? How many are engaging in income-generating projects so that when they retire, their businesses are already stable and can support their everyday upkeep?

A study made by Annamaria Lusardi (2011) mentioned that in the United States, the working populace, and their families are now concerned with their financial security. It is the reason why a tremendous shift in the attitude on retirement preparation today compared to the 1980s. Accordingly, Americans are now investing in different financial portfolios.

In the Philippines (East Asia Retirement Survey, 2015), 90\% of the Filipinos are now afraid that when they retire, they become impoverished. It is because the usual retirement packages that a retiree can expect are the lump sum of their retirement pay, benefits from the Social Security System (SSS) for private employees, PhilHealth benefit (for hospitalization) and PAG-Ibig dividend. But with the increasing life expectancy, would it suffice to say that these amounts of money could withstand until such time when the person demise? Thus, if a retiree wants to maintain their current lifestyle, careful retirement planning should be done.

Studies made by authors from all over the world, like Lusardi and Mitchell (2007, 2009); Andrade, Bazelais and Das (2014); Bucher-Koenen and Lusardi (2011); Uppa (2016); Agnew, et al., (2015); and Arrondel, et al., (2014), showed the importance of financial literacy in financial planning. They further cited in the research that a worker could only prepare for his retirement if he or she is financially literate. 
Financial literacy refers to percepts on awareness and knowledge of business and finance, including the difference of the financial products available in the market or by the different financial institutions. It includes the ability of the individual to make calculations on compound interest, management of finances and planning the financial resources $(\mathrm{Xu}$ and Zia, 2012).

The findings of the importance of financial literacy vis-a-vis retirement preparedness in the United States and the other parts of the world prompted the researcher to investigate its relationship and applicability in her workplace, the University of Bohol taking into account that the average age of the working populace is 42 years old.

The primary goal of this research was to assess the relationship between financial literacy and retirement preparedness among the employees of the University of Bohol. Specifically, it determined the level of financial literacy and retirement preparedness among University of Bohol (UB) employees. It also examined the significant degree of relationship between the profile of the employees and the financial literacy and retirement preparedness and the significant degree of correlation between financial literacy and retirement preparedness. The result of the research will serve as the basis in attaining the employees' goal for their retirement preparation and will form part of their corporate social responsibility (CSR) project for the employees.

The retirement plan that an individual make affects their financial security in their twilight years and happiness. The following theories and related studies were gathered to have a sturdier theoretical framework:

The economic theory on Life Cycle Hypothesis (Modigliani and Brumberg, 1954), states that the savings ratio of a person depends on its income. Their consumption and savings plan, including their retirement planning, lies over their lifecycle. People started to save a considerable amount during the time that their earning is high through wealth accumulation and consuming what they make after their retirement. However, based on the Rational Choice Theory (Homans, 1961), man is logical by nature, and their individual decision lies in the context that it will give satisfaction through rewards or monetary value. An individual can make a satisfactory decision given the alternatives set to them. But the intention to have a retirement plan is based on the norms, attitude and perceived control which dictates the motive of an individual (Theory of Planned Behavior, Ajzen, 1991). The motivational theory, Maslow's 
Hierarchy of Needs further validated that people aim to meet basic needs and once the fulfillment of the lower echelon is fulfilled, time and attention to additional requirements like love and belongingness, friendship and family, will be given importance. That is why it is hard to pay much attention to the higher-order needs if there is a threat in the lower order needs. And that can easily happen when there is an insufficient preparation for the person's retirement years.

Bernheim $(1995,1998)$ noted that policymakers and researchers might have overlooked the importance of financial literacy to explain savings and differences in saving behavior. In Europe, multiple regression analyses lead to conclusions that advanced levels of financial literacy have an active and significant effect on retirement planning among Dutch students after controlling for various demographic factors such as age, income and class rank. However, the findings made by Lusardi and Mitchell (2007c; 2009) and van Rooij et al. (2011a) among the American and Dutch population is consistent that the financial literacy among students is lacking (Chen and Volpe, 1998; Beal and Delpachitra, 2003). By combining these two elements, it becomes clear that future generations will need to improve their financial knowledge to prepare for retirement adequately.

In East Asia, relatively few of today's workers expect to have "a lot less income" in retirement than they do now. While 45 percent of current retirees report that this is the case, just 16 percent of the workers expect it to happen when they retire (Jackson \& Peter 2015).

Developing countries have low levels of financial literacy. In a study in India, more than half of the respondents showed that they prefer to put their savings at home and borrowed money at an exorbitant interest rate which worsen their financial situation. The shortfall on financial literacy is based on the shortage of the entry of the different financial products or the failure to use these products even when they are available. In Zambia and six other African countries, there are only 29 percent adults that have a bank account while 50 percent of them has no financial products at all. In South Africa, a recent survey found that nearly 60 percent of the people surveyed do not understand the term "interest." (World Bank, 2009)

In another study made by Lusardi and Mitchell (2007), it indicates that people were showing higher levels of financial literacy when young are more likely to plan for retirement. Furthermore, they found that financial literacy is highly related to exposure to economics in school. On the other 
hand, multiple researchers (Chen and Volpe, 1998; Beal and Delpachitra, 2003) found that students in the U.S. and Australia, some even with a background in business, are not skilled in financial matters, which also includes retirement investment decisions. There is a shadow of a doubt if future generations can plan for retirement.

Another financial literacy study among four countries made by Nicollin, G. et al. (2013) revealed that there is a significant difference among countries. It showed that there are national and cultural differences in what households know and need to know about their finances. Thus, they recommend that policymakers should consider these differences when developing financial literacy assessment tools for their respective countries.

A study on the retirement readiness of the three-generation was made by Trans America Center for Retirement Studies (2014). It showed that the many of the baby boomers (born 1946 -1964), still have to think a process so that they can continue working and have a backup plan if retirement happens unexpectedly. For the generation X (1965-1978) or the 401(k) Generation, they estimated that they need an average retirement savings of one million. On the other hand, the young professionals or millennial (1979 - 1996) are starting to save and are taking hold of the latest innovations on their employer-sponsored retirement plans. They are hungry for more information on how to achieve their retirement goals especially that it is digitally available. With these three generational differences, we can also see how the Filipino counterparts are doing or if they also have the same attributes.

The East Asia Retirement Survey made by Prudential Corporation Asia for the Philippines (Jackson, Peter, 2015) revealed that $90 \%$ of the Filipinos are anxious that when they retire, they have insufficient savings and in need of money. While others are bothered that they will become a burden to their children, become sickly, and nobody will take care of them. That is why, even after retirement, some of them are still working to make ends meet. However, based on the 2013 SWS survey, thirty-nine percent $(39 \%)$ of Filipinos try to save regularly. There is only thirty-two percent $(32 \%)$ have a saving habit while ten percent $(10 \%)$ sees no need to make a saving since their income is not enough anyway.

In the Philippines, the study of Mandigma (2014) showed that Filipinos presented positive attitudes towards savings for retirement, but these 
attitudes were not related at all to their retirement plan preferences. Levels of financial knowledge were awe-inspiring, but curiously, they were not correlated to the importance of retirement plans.

\section{METHODOLOGY}

The study applied a quantitative, descriptive, normative survey method was made and used a modified survey questionnaire. The financial literacy part of the survey questionnaire was adapted from the study of Nestor van Dijk (2012), "The Effect of Financial Literacy on Retirement Planning among Dutch Students" but it was modified for the better understanding of the respondents. Universal purposive sampling technique was used.

The research study was conducted in the different departments and offices at the University of Bohol. The University of Bohol (previously known as Rafael Palma College) was established in 1946. It is a private non-sectarian co-educational institution of higher learning in Tagbilaran City, Bohol, Philippines. At present, the University of Bohol has 16 departments, which comprise the UB Grade School, UB High School, UBVDT Advance Learning Center and 12 Colleges and the Graduate School and Professional Studies. It also has 17 offices, which served as support units.

This study made use of a survey questionnaire to determine the financial literacy and retirement preparedness of the UB employees.

Twenty financial literacy questions were included in the survey questionnaire to assess the financial awareness and knowledge, financial capability, money management and financial planning of the UB teaching and non- teaching staff.

After all the quantitative data were collected, it was coded to ensure the confidentiality of the data and encoded using Microsoft Excel. The variables in the study served as major categories for data coding. Data on financial literacy and retirement preparedness were subjected to statistical treatments, analyzed, compared and checked for similarities or differences.

The simple percentage formula was used to determine the profile of the respondents when it comes to their age, sex, civil status, highest educational attainment, employment status, the length of service, and department assigned. 
The responses of the respondents were checked according to the correct answers for each question. The right answers were summed up and categorized to determine the level of literacy.

The degree of conformity of the respondents on the items on retirement preparedness was tallied and summed up. The weighted mean of the frequency of the level agreement was computed to determine its level of readiness.

For further analysis, the study made use of Pearson Product Moment Correlation to measure the steadiness and order of association that exists between two variables measured on at least an interval scale. The Pearson product-moment correlation was used to higher-order for the correlation between age and length of service with the level of financial literacy and retirement preparedness; and a relationship between financial literacy and retirement preparedness. In assessing the goodness of fit between observed values and those expected theoretically using Chi-square test. This test was used to verify the relationship of sex, civil status, educational attainment, employment status and type of employment with the level of financial literacy and retirement preparedness. On the other hand, in assessing whether the means of two groups are statistically different from each other using the t-test was. In this paper, it was used to determine the significant degree of difference between male and female UB employees in their financial literacy and retirement preparedness.

\section{FINDINGS AND RESULTS}

\section{Level of Financial Literacy}

Twenty financial literacy questions were included in the survey questionnaire to assess the financial awareness and knowledge, financial capability, money management and financial planning of the UB teaching and non-teaching staff. The questions were divided into four groups namely: a) fundamental concepts (questions 1-3) relating to financial literacy, which comprises of calculation of numeracy, compound interest, inflation, simple financial decision; (b) basic financial awareness (question 4-6); (c) financial attitudes and perceptions (questions 7-13) and (d) advanced economic concepts relating to financial literacy (questions 14-20) which comprises on the respondent's knowledge of financial instruments like bonds, stocks and the like. 
Based on the result of the financial literacy survey in Figure 5, the highest financial literacy question that they have answered correctly, in which $84 \%$ of the respondents were able to answer, is the question no. 11, "Which of the following can hurt your credit standing?" It means that UB employees knowledgeable in the mechanics of lending and their responsibilities as the creditor. According to the interview conducted with some employees, they are familiar with this because as members of Credit Union and cooperatives, they have made loans while some have credit cards and loans from other institutions. They knew that once they cannot repay their debts on time, there is a big possibility that their credit standing will be affected not to mention the additional interest incurred. The question that ranks 2 nd $(82 \%)$ in the number of employees with the correct answer is question number no. 13, "Which of the following will help lower the cost of a house?" Interview from some of the employees revealed that building a house is one of their top priorities. Hence, when they made a loan from PAG-Ibig, they opted to pay a bigger equity so that the principal will decrease which in return, lowering down the amortization. The 3rd highest correct answer $(75 \%)$ is number 3 , "Let's say you're in a grocery store and you wanted to buy one kilogram of powdered milk for your child. Which of the following will you buy?" It can be deduced that most employees know the economies of scale.

With the result of the three-highest correct answer, a conclusion can be drawn that the respondents were knowledgeable with the ins and outs of credit or lending practices, familiar on how to make a housing loan and how to protect their credit standing. In this instance, we can say that indeed UB employees have a healthy financial attitude and perception and somehow made some retirement planning by securing their family through the provision of their abode.

Table 1 summarized the results of the survey and grouped according to the level of literacy

Table 1. Level of Financial Literacy among University of Bohol Employees

\begin{tabular}{|c|c|c|c|c|}
\hline Level of Literacy & Scores & F & $\%$ & $\mathbf{R}$ \\
\hline High & $16-20$ & 12 & 7.50 & 4 \\
\hline Moderate & $11-15$ & 71 & 44.38 & 1 \\
\hline Fair & $6-10$ & 60 & 37.50 & 2 \\
\hline Low & $0-5$ & 17 & 10.63 & 3 \\
\hline
\end{tabular}


Sum: 160

Mean: 10.43 - FAIR

Standard Deviation: 3.7224

Based on the table, it revealed that seventy-one (71) out of onehundred sixty (160) respondents or $44.38 \%$ were moderately literate while sixty or $37.50 \%$ have a fair level of financial literacy. Seventeen or $10.63 \%$ of the respondents obtained a low level of financial literacy. On the other hand, twelve (12) or $7.50 \%$ have a correct answer ranging from $16-20$ and with a high financial literacy rating. It showed that almost majority of the employees have a moderate level of financial literacy. However, the derived computed mean is only 10.43 , which can be interpreted as a fair level of financial literacy. With this result, it can then be deduced that on an average, UB employees can fairly understand the fundamental and advanced concepts relating to financial literacy, has the basic financial awareness and has the right financial attitudes and perceptions that are needed in investment and decision-making.

\section{Level of Retirement Preparedness}

Table 2. Level of Retirement Preparedness of the Respondents

$$
\mathrm{N}=160
$$

\begin{tabular}{|c|c|c|c|c|c|c|c|c|}
\hline \multicolumn{1}{|c|}{ Items } & $\begin{array}{c}\text { SA } \\
(4)\end{array}$ & $\begin{array}{c}\text { A } \\
(3)\end{array}$ & $\begin{array}{c}\text { D } \\
(2)\end{array}$ & $\begin{array}{c}\text { SD } \\
(1)\end{array}$ & N & WM & DV & Rank \\
\hline $\begin{array}{c}\text { 1. I have established and quantified } \\
\text { my financial objectives (needs } \\
\text { and wants). }\end{array}$ & 33 & 98 & 20 & 4 & 155 & 3.03 & MP & 4 \\
\hline $\begin{array}{c}\text { 2. I keep track on my money based } \\
\text { on my objective. }\end{array}$ & 37 & 98 & 15 & 4 & 154 & 3.09 & MP & 2 \\
\hline $\begin{array}{c}\text { 3. I see to it that all my needs are } \\
\text { provided before I buy my wants. }\end{array}$ & 73 & 76 & 6 & 2 & 157 & 3.40 & HP & 1 \\
\hline $\begin{array}{c}\text { 4. I stay informed on financial } \\
\text { issues. }\end{array}$ & 41 & 83 & 32 & 0 & 156 & 3.06 & MP & 3 \\
\hline 5. I have decided when to retire. & 32 & 61 & 53 & 10 & 156 & 2.74 & MP & 5 \\
\hline 6. I have made my retirement plan. & 17 & 61 & 65 & 13 & 156 & 2.53 & MP & 7 \\
\hline $\begin{array}{l}\text { 7. I have prepared my estimated } \\
\text { retirement budget. }\end{array}$ & 27 & 45 & 62 & 19 & 153 & 2.52 & MP & 8 \\
\hline $\begin{array}{c}\text { 8. I have computed the possible } \\
\text { SSS/GSIS/Pag IBIG/ PERAA } \\
\text { UB Retirement benefits that I'II } \\
\text { get when I retire. }\end{array}$ & 16 & 46 & 72 & 20 & 154 & 2.38 & SP & 10 \\
\hline
\end{tabular}




\begin{tabular}{|c|c|c|c|c|c|c|c|c|}
\hline $\begin{array}{l}\text { 9. I shop around to get the best } \\
\text { financial product for my } \\
\text { retirement package. }\end{array}$ & 10 & 48 & 79 & 17 & 154 & 2.33 & SP & 11 \\
\hline $\begin{array}{l}\text { 10.I asked the help of professional } \\
\text { financial advisers, families, } \\
\text { and friends on the appropriate } \\
\text { financial product for my } \\
\text { retirement. }\end{array}$ & 18 & 50 & 69 & 17 & 154 & 2.45 & SP & 9 \\
\hline $\begin{array}{l}\text { 11. I have made investments in } \\
\text { preparation for my retirement. }\end{array}$ & 19 & 64 & 58 & 14 & 155 & 2.57 & MP & 6 \\
\hline Composite Mean & & & & & & 2.74 & MP & \\
\hline Parameters: & & & & & & & & \\
\hline & 1.00 & 1.74 & NP & \multicolumn{3}{|c|}{ Not Prepared } & & \\
\hline & 1.75 & 2.49 & $\mathrm{SP}$ & \multicolumn{3}{|c|}{ Slightly Prepared } & & \\
\hline & 2.50 & 3.24 & MP & \multicolumn{4}{|c|}{ Moderately Prepared } & \\
\hline & 3.25 & 4.00 & $\mathrm{HP}$ & \multicolumn{3}{|c|}{ Highly Prepared } & & \\
\hline
\end{tabular}

Based on the computation, the over-all composite mean for the level of retirement is 2.74 , meaning to say that the employees are moderately prepared (See Table 2).

Table 3. Summary of the Relationship Between Respondent's Profile and Level of Financial Literacy

\begin{tabular}{|c|l|l|}
\hline Demographic Profile & Result of the Statistical Treatment & \multicolumn{1}{|c|}{ Analysis } \\
\hline Age & $\begin{array}{l}r=-0.19338>\text { critical value of } r \text { at } \\
158 \mathrm{df}(0.05)=0.13428\end{array}$ & $\begin{array}{l}\text { Significant; } \\
\text { Ho = rejected; correlated }\end{array}$ \\
\hline Length of Service & $\begin{array}{l}r=-0.16397>\text { critical value of } \mathrm{r} \text { at } \\
156 \mathrm{df}(0.05)=0.13636\end{array}$ & $\begin{array}{l}\text { Significant; } \\
\text { Ho = rejected; correlated }\end{array}$ \\
\hline Sex & $\begin{array}{l}\mathrm{x}^{2}=6.3237<\text { critical value @ 3 df } \\
(0.05)=7.81\end{array}$ & $\begin{array}{l}\text { Insignificant; Ho = accepted; no } \\
\text { relationship }\end{array}$ \\
\hline Civil Status & $\begin{array}{l}\mathrm{x}^{2}=8.8137<\text { critical value @ } \\
6 \mathrm{df}(0.05)=12.59\end{array}$ & $\begin{array}{l}\text { Insignificant; Ho = accepted; no } \\
\text { relationship }\end{array}$ \\
\hline Highest Educational & $\begin{array}{l}\mathrm{x}^{2}=15.0470<\text { critical value @ 9 df } \\
(0.05)=16.92\end{array}$ & $\begin{array}{l}\text { Insignificant; Ho = accepted; no } \\
\text { relationship }\end{array}$ \\
\hline Employment Status & $\begin{array}{l}\mathrm{x}^{2}=5.9041<\text { critical value @ 9 df } \\
(0.05)=16.92\end{array}$ & $\begin{array}{l}\text { Insignificant; Ho = accepted; no } \\
\text { relationship }\end{array}$ \\
\hline Type of Employment & $\begin{array}{l}\mathrm{x}^{2}=9.8643>\text { critical value @ 3 df } \\
(0.05)=7.81\end{array}$ & $\begin{array}{l}\text { Significant; Ho = rejected; with } \\
\text { relationship }\end{array}$ \\
\hline
\end{tabular}


Based on the Pearson's Moment $r$ and Chi-square, the age, length of service and type of employment has a relationship with the level of financial literacy (See Table 3). The findings showed that there is a negative linear relationship between age and length of service with the level of financial literacy. The younger generation or the millennial and the newly employed has a slightly higher level of financial literacy than their older contemporaries. It can be attributable to the fact that the millennial generation was educated on the basic concepts of finance as early as grade school and topics like investments, retirement, savings were frequently discussed by the millennial to their family and friends. The types of employment, whether they are teaching or non-teaching have a relationship with the level of financial literacy.

Table 4. Summary of the Relationship Between Respondent's Profile and Level of Retirement Preparedness

\begin{tabular}{|c|l|l|}
\hline $\begin{array}{c}\text { Demographic } \\
\text { Profile }\end{array}$ & \multicolumn{1}{|c|}{ Result of the Statistical Treatment } & \multicolumn{1}{c|}{ Analysis } \\
\hline Age & $\begin{array}{l}r=0.24824>\text { critical value of } \\
r @ 155 \mathrm{df}(0.05)=0.1374\end{array}$ & $\begin{array}{l}\text { Significant; } \\
\text { Ho = rejected; correlated }\end{array}$ \\
\hline Length of Service & $\begin{array}{l}\mathrm{r}=0.17170>\text { critical value of } \mathrm{r} \text { at } 153 \mathrm{df} \\
(0.05)=0.1398\end{array}$ & $\begin{array}{l}\text { Significant; } \\
\text { Ho = rejected; correlated }\end{array}$ \\
\hline Sex & $\begin{array}{l}\mathrm{x}^{2}=14.3709>\text { critical value } \\
@ 3 \mathrm{df}(0.05)=7.81\end{array}$ & $\begin{array}{l}\text { Significant; Ho = rejected; } \\
\text { there is a relationship }\end{array}$ \\
\hline Civil Status & $\begin{array}{l}\mathrm{x}^{2}=8.3646<\text { critical value @ 6 df }(0.05) \\
=12.59\end{array}$ & $\begin{array}{l}\text { Insignificant; Ho = accepted; } \\
\text { no relationship }\end{array}$ \\
\hline $\begin{array}{c}\text { Highest Educational } \\
\text { Attainment }\end{array}$ & $\begin{array}{l}\mathrm{x}^{2}=10.1558<\text { critical value } \\
@ 9 \mathrm{df}(0.05)=16.92\end{array}$ & $\begin{array}{l}\text { Insignificant; Ho = accepted; } \\
\text { no relationship }\end{array}$ \\
\hline $\begin{array}{c}\text { Employment Status } \\
\mathrm{x}^{2}=10.7099<\text { critical value @ 9 df (0.05) } \\
=16.92\end{array}$ & $\begin{array}{l}\text { Insignificant; Ho = accepted; } \\
\text { no relationship }\end{array}$ \\
\hline $\begin{array}{c}\text { Type of } \\
\text { Employment }\end{array}$ & $\begin{array}{l}\mathrm{x}^{2}=6.5276>\text { critical value @ 3 df (0.05) } \\
=7.81\end{array}$ & $\begin{array}{l}\text { Insignificant; Ho = accepted; } \\
\text { no relationship }\end{array}$ \\
\hline
\end{tabular}

Based on Table 4, the two factors, such as age and length of service having a positive correlation value with retirement preparedness denotes that as an employee aged and their stay in the university increases, the preparation for their life after retirement also rises.

Regarding sex and its relationship to retirement preparation, it is more apparent that the male employees are more intense in retirement 
preparation compared to the female employees. However, it should be subjected to further statistical treatment to determine the difference.

Table 5. Correlation between level of financial literacy and level of retirement preparedness among UB employees

\begin{tabular}{|c|c|c|c|c|c|}
\hline \multirow{2}{*}{ Employees } & \multicolumn{2}{|c|}{ Literacy Level } & Retirement Preparedness & \multirow{2}{*}{ XY } \\
\cline { 2 - 5 } & $\mathrm{X}$ & $\mathrm{X}^{2}$ & $\mathrm{Y}$ & $\mathrm{Y}^{2}$ & \\
\hline $\mathrm{N}=157$ & & & & & \\
\hline Sum & 1647.00 & 19367 & 430.81 & 1230.31 & 4454.01 \\
\hline Mean & 10.49 & & 2.74 & & \\
\hline SD & 3.6596 & & 0.5557 & \\
\hline \multicolumn{6}{|c|}{ Critical Value of $\mathrm{r}$ at 155 df $(0.05)=0.1374$} \\
\hline \multicolumn{6}{|c|}{ Result: Significant } \\
\hline
\end{tabular}

As shown in Table 5, there is a negative correlation between financial literacy and level of retirement readiness based on the computed value of $r$ of -0.20599 is greater than the critical value 0.1374 at 155 degrees of confidence and 0.05 confidence level. With these figures, it can be inferred that the UB employees are doing some preparations for their retirement even though they are not that highly knowledgeable in financial management or other financial decisions. Some of them do not know anything about stocks, bonds, mutual funds and other financial instruments, but they invest in what they can understand like putting money in the savings bank, time deposits, cooperatives and the like.

Table 6. Difference between the level of financial literacy of the male and female employees

\begin{tabular}{|c|c|c|c|c|c|}
\hline \multicolumn{6}{|c|}{$\begin{array}{l}\text { Difference Between the Level of Financial Literacy of the } \\
\text { Male and Female Employees }\end{array}$} \\
\hline \multicolumn{3}{|c|}{ Male } & \multicolumn{3}{|c|}{ Female } \\
\hline Employees & $\left(x_{1}\right)$ & $\left(x_{1}^{2}\right)$ & Employees & $\left(x_{2}\right)$ & $\left(x_{2}^{2}\right)$ \\
\hline Sum & 625 & 7009 & Sum & 1043 & 12583 \\
\hline Mean & 9.62 & & Mean & 10.98 & \\
\hline Difference & -1.36 & & & & \\
\hline Standard Deviation & 3.9516 & & Standard Deviation & 3.4827 & \\
\hline $\mathrm{N}$ & 65 & & & 95 & \\
\hline & & tunc $=$ & -2.3064 & & \\
\hline
\end{tabular}


Critical Value of $\mathrm{t}$ at $158 \mathrm{df}(0.05)=1.960$

Result: Significant

Ho: Rejected

Another hypothesis that was statistically treated is the determination if there are no differences between the level of financial literacy of male and female employees (See Table 6). Based on the result of the t-test, it shows that there is a statistically significant difference between males (M $=9.62, \mathrm{SD}=3.9516)$ and females $(\mathrm{M}=10.98, \mathrm{SD}=3.4827)$ on financial literacy. Thus, the null hypothesis was rejected. With this computation, it can be construed that there is a gender disparity in favor of the females in the population concerning financial literacy. It is in contrast with findings of the study, "Planning and Financial Literacy: How Do Women Fare?" made by Lusardi and Mitchell (2008) wherein they concluded that women exhibit a lower financial literacy.

Table 7. Difference Between the Level of Retirement Preparedness of the male and female employees

\begin{tabular}{|c|c|c|c|c|c|}
\hline \multicolumn{3}{|c|}{ Male } & \multicolumn{3}{|c|}{ Female } \\
\hline Employees & $\left(x_{1}\right)$ & $\left(x_{1}^{2}\right)$ & Employees & $\left(x_{2}\right)$ & $\left(x_{2}^{2}\right)$ \\
\hline Sum & 190.98 & 580.80 & & 245.95 & 669.17 \\
\hline Mean & 2.94 & & & 2.62 & \\
\hline Difference & 0.32 & & & & \\
\hline Standard Deviation & 0.5540 & & & 0.5251 & \\
\hline $\mathrm{N}$ & 63 & & & 94 & \\
\hline & & tunc $=$ & 4.6935 & & \\
\hline \multicolumn{6}{|c|}{ Critical Value of $t$ at $158 \mathrm{df}(0.05)=1.960$} \\
\hline \multicolumn{6}{|c|}{ Result: Significant } \\
\hline \multicolumn{6}{|c|}{ Ho: Rejected } \\
\hline
\end{tabular}

The hypothesis that there are no differences between the level of retirement preparedness between male and female employees was also subjected to a statistical treatment (See Table 7). Thus, there is a statistically significant difference between males $(M=2.94, S D=0.5540)$ and females $(M=2.62, S D=0.5251)$ on retirement preparedness and rejecting the null hypothesis. The discrepancy is in favor of the male population. Meaning to say, the male employees of the university are keen in preparing for his retirement rather than the female populace. 


\section{CONCLUSIONS}

Based on the findings presented, the following conclusions were derived:

1. It is not necessary that an employee has a high level of financial literacy to prepare for his life after employment. It is apparent with the result of the survey conducted wherein the UB Employees that though their average level of financial literacy is fair, they are moderately prepared when it comes to retirement.

2. The young professionals are slightly literate than their older counterparts. It can be attributed that to the fact that they were taught the basic financial concept as early as grade school and they talked about financial matters and investments to their friends and families. However, when it comes to retirement preparedness, most of them do not have any investments allotted for retirement. Some are still helping their parents while others save for their post-graduate needs and want.

3. Female employees are more literate than their male counterparts, but it is the male employees who are more prepared regarding retirement.

4. Retirement Preparedness is important. Interviews from the retirees revealed that financial preparedness is needed especially if a person does not have a business prowess. The retirement pay from UB can be easily used up, and the SSS pension is way below the salary received when they are still working, and it should be budgeted because it is just enough for their everyday upkeep.

5. RetirementPreparedness regarding coping with life after employment should also be addressed. One retiree got sick after retirement because of the change in lifestyle. One retiree even recommended a seminar on this topic.

\section{REFERENCES}

Agnew, S., \& Harrison, N. (2015) Financial literacy and student attitudes to debt: A cross-national study examining the influence of gender on personal finance concepts, Journal of Retailing and Consumer Services, 25, 122-129. Retrieved from goo.gl/to, (accessed last 27 June 2017). 
Arrondel, L., Debbich, M., \& Savignac, F. (2014). Financial literacy and financial planning in France. Retrieved from https://goo.gl/bFovfv, (accessed last 24 June 2017).

Ajzen, I. (1991). The theory of planned behavior. Organisational behavior and human decision processes, 50 (2), 179-211). Retrieved from goo. $\mathrm{gl} / \mathrm{bzwL2B}$, (accessed last 28 June 2017).

Beal, D. J., \& Delpachitra, S. B. (2003). Financial literacy among Australian university students. Economic Papers: A journal of applied economics and policy, 22(1), 65-78. Retrieved from goo.gl/fCxDFh, (accessed last 28 June 2017).

Chen, H., \& Volpe, R. P. (1998). An analysis of personal financial literacy among college students. Financial services review. 7(2), 107-128. Retrieved from goo.gl/2dngk3, (accessed last 27 June 2017).

Peter, T., R. Jackson (2015). From Challenge to Opportunity: Wave 2 of the East Asia Retirement Survey. Retrieved from www. prudentialcorporation-asia.com/eastasia-retirement-2015, (accessed last 26 June 2017).

Lusardi, A., \& Mitchell, O. S. (2011). Financial literacy around the world: an overview. Journal of Pension Economics and Finance, 10(04), 497508. Retrieved from https://goo.gl/mUUFuh, (accessed last 24 June 2017).

Lusardi, A., \& Mitchell, O. S. (2011). Financial literacy and planning: Implications for retirement wellbeing (No. w17078). National Bureau of Economic Research. Retrieved from https://goo.gl/EKyogh, (accessed last 24 June 2017).

Lusardi, A., \& Mitchell, O. S. (2011). Financial literacy and retirement planning in the United States. Journal of pension economics and finance, 10(04), 509-525. Retrieved from https://goo.gl/DTN37L, (accessed last 24 June 2017).

Lusardi, A., \& Mitchell, O. S. (2008). Planning and financial literacy: How do 
women fare? (No. w13750). National Bureau of Economic Research. Retrieved from https://goo.gl/vBBh96, (accessed last 24 June 2017).

Lusardi, A., \& Mitchell, O. S. (2007). Financial literacy and retirement planning: New evidence from the Rand American Life Panel. Michigan Retirement Research Center Research Paper No. WP, 157. Retrieved from https://goo.gl/CtKFqj, (accessed last 24 June 2017).

Lusardi, A., \& Mitchelli, O. (2007). Financial literacy and retirement preparedness: Evidence and implications for financial education. Business economics, 42(1), 35-44. Retrieved from https://goo.gl/ EniHtQ).

Mandigma, M. B. S. (2014). Retirement Plans Preferences in the Philippines. International Proceedings of Economics Development and Research, 71, 64. Retrieved from http://www.ipedr.com/vol71/012ICCKS2014_S10002.pdf, (accessed last 24 June 2017).

Modigliani, Franco (1966). "The Life Cycle Hypothesis of Saving, the Demand for Wealth and the Supply of Capital." Social Research. 33 (2): 160-217. JSTOR 40969831. Retrieved from https://goo.gl/ TeCb1A, (accessed last 24 June 2017).

Social Weather Stations (SWS) Survey 2013. Retrieved from https://goo. gl/Jc3Fk4, (accessed last 25 June 2017).

Uppal, S. (2016) Financial Literacy and Retirement Planning. Statistics Canada. Retrieved from goo.gl/hNwW8M, (accessed last 28 June 2017).

Van Rooij, M., Lusardi, A., \& Alessie, R. (2011). Financial literacy and stock market participation. Journal of Financial Economics 101, (2), 449472. Retrieved from goo.gl/xKvReh, (accessed last 28 June 2017).

Xu, L., \& Zia, B. (2012). Financial literacy around the world: an overview of the evidence with practical suggestions for the way forward. World Bank Policy Research Working Paper, (6107). Retrieved from https:// goo.gl/izeu4x, (accessed last 24 June 2016). 